\title{
Cheias de GRAÇA: AS POÉtiCAS MAMBEMBES DE Guimarães Rosa e OSMan Lins
}

\author{
FULL OF GRACE: THE POETICS OF THE MINIMUM IN THE \\ WORKS OF GUIMARÃEs ROSA AND OSMan LINS
}

\section{Ermelinda Maria Araújo Ferreira}

Universidade Federal de Pernambuco

Recife

Brasil

\section{Resumo}

Este ensaio discute a agraciada força das poéticas "menores" de dois grandes vates da literatura brasileira moderna: Guimarães Rosa e Osman Lins, através da análise do papel do riso e da comicidade na construção metalinguística de algumas de suas obras, que refletem, cada uma a seu modo, uma visão de mundo curiosamente próxima - afeita aos princípios da carnavalização e do circo. A alegria é, para esses escritores, a pedra fundamental de uma estética do insignificante e do ínfimo, e de uma ética profundamente humana, de vida, morte e renovaçáo.

Palavras-chave: infância; circo; comédia; fábula; Guimarães Rosa; Osman Lins.

\section{Abstract}

This essay discusses the blessed strength of the poetics of the "minor" literature of Guimaraes Rosa and Osman Lins, two big vates of modern Brazilian literature. We discuss the role of laughter and comedy in some metalinguistic constructions of their works that reflect, each in its way, a worldview curiously close and accustomed to the principles of carnivalization and circus. Joy is, for these writers, the cornerstone of an aesthetics of the small and the insignificant; and of a deeply human ethics of life, death and renewal. Keywords: infancy; circus; comedy; fable; Guimarães Rosa; Osman Lins.

\section{Resumen}

Este ensayo analiza la fuerza de poética galardonado "menor" de dos grandes vates de la literatura brasileńa moderna: Guimarães Rosa y Osman Lins, examinando el papel de la risa y el humor en la construcción metalingüística de algunas de sus obras que reflejan cada uno de los a su manera, una visión del mundo con curiosidad siguiente - acostumbrado a los principios de la carnavalización y circo. La alegría es, para estos autores, la piedra angular de una estética de la insignificante y despreciable; y de una ética profundamente humana, de la vida, la muerte y la renovación.

Palabras clave: infancia; circo; comedia; fábula; Guimarães Rosa; Osman Lins. 
Cheias de graça - tocadas pela dádiva divina que produz o gracejo bom, o atrativo belo e o dom verdadeiro: esta parece ser a trindade temperamental das poéticas mambembes de Guimarães Rosa e Osman Lins. Graves, inspiradas, iluminadas; mas também engraçadas, gratuitas, gratificantes. Pareceria um contrassenso atribuir às poéticas de escritores da estatura/envergadura dessa dupla o adjetivo "mambembe" - sinônimo de ignóbil, reles, inferior, ínfimo, insignificante, banal -, não fosse a autorização que nos concedem alguns de seus textos, particularmente aqueles que refletem, genérica ou confessionalmente, sobre a infância, e que por isso vêm carregados de líricas conotaçóes ao anódino e à simplicidade.

Tais textos costumam se referir, direta ou indiretamente, a um tipo de representação teatral surgida na Europa medieval, quando artistas nômades malabaristas, equilibristas, ilusionistas, músicos e bufôes -, fugindo da perseguição da Igreja, começaram a viajar em carroças, apresentando seus espetáculos em troca de dinheiro, alimento e hospedagem. A palavra "mambembe", provavelmente, vem de "zambembe" - "errante", utilizada para essas trupes amadoras, que dispunham de poucos recursos e sobreviviam apenas de passar o chapéu, de cidade em cidade. Como eram essencialmente itinerantes, esses artistas não podiam cultivar posturas cênicas elaboradas, nem utilizar grandes cenários ou figurinos complicados, que demandassem manutenção dispendiosa. No Brasil, a expressão "mambembe" surgiu, provavelmente, entre os séculos XVII e XVIII, atribuída a grupos teatrais que apresentavam espetáculos popularescos, às vezes improvisados, artesanais e sem recursos tecnológicos.

Não há como não perceber a franca - conquanto elaborada - inclinaçáo mambembe da poética rosiana, traduzida no enigmático título de sua última coletânea de contos, Tutaméia (Terceiras estórias), que veio a público poucos meses antes da morte do autor, em novembro de 1967, e que representa, segundo Walnice Nogueira Galvão, "o mais minimalista dos livros de Guimarães Rosa". Constituído por quarenta narrativas de curta extensão (três a cinco páginas) e quatro prefácios de cunho metalinguístico, cujo ambicioso propósito é refletir sobre os pilares de sua obra - mea omnia -, Tutaméia representa uma espécie de mapa - theatrum orbis terrarum - da monumental e densa travessia literária deste autor. Surpreendentemente, porém, ele insiste em desmistificar a crítica, construindo para si uma irreverente autoanálise, saindo em defesa "da comicidade e do humorismo como catalisadores ou sensibilizantes ao alegórico espiritual e ao não-prosaico. Risada e meia?”:

A estória não quer ser história. A estória, em rigor, deve ser contra a História. A estória, às vezes, quer-se um pouco parecida à anedota. ... Uma anedota é como 
um fósforo: riscado, deflagrada, foi-se a serventia. ... Não será sem razão que a palava "graça" guarde os sentidos de gracejo, de dom sobrenatural e de atrativo. ...O livro pode valer muito pelo que nele não deveu caber. (ROSA, 1967: 3)

No glossário inserido no derradeiro prefácio, "Sobre a escova e a dúvida", o significado de "tutaméia" é elencado ao lado das definiçôes jocosas de outros verbetes, nem todos presentes no livro: "tutaméia: nonada, baga, ninha, inânias, ossos-de-borboleta, quiquiriqui, tuta-e-meia, mexinflório, chorumela, nica, quase-nada; mea omnia"(ROSA, 1967: 166). Há, portanto, neste livro, o diálogo entre dois Guimarães Rosa: o teórico dos prefácios e o ficcionista dos minicontos. O teórico dos prefácios, autor de sólida "crítica interna", é responsável pela construção de um arcabouço erudito/explicativo de grande valor para o entendimento da proposta do livro e, por extensão, do vasto orbis que ele sintetiza. Mas a teorização que ele leva a cabo de sua prática criativa se faz através de textos que se assemelham e se somam à própria prática, e assim conseguem escapar ao pedantismo de que padece a crítica literária institucional, ao abrir espaço para as suas hermenêuticas sem nenhuma aletrialalegria.

Já o Guimarães Rosa ficcionista dos minicontos, aquele que deve pôr em prática a teoria dos prefácios em curtas estórias despojadas do "h" - seja o dos assuntos sérios da história documental; seja o dos assuntos supostamente destituídos de seriedade da ficção; seja, ainda, o da própria hermenêutica - é alguém que não prescinde da consciência do valor exemplar dessas narrativas, face aquilo que as move e as subordina, que é o sentido. Versando sobre a graça, a ignorância e o riso, esses prefácios incorporam o espírito indômito da criança, e não são raras, entre as suas narrativas, aquelas protagonizadas pelo Menino - quase sempre máscaras (autobiográficas?) de um adorável e recorrente Miguilim - de Miguel, o arcanjo, "aquele que é similar a Deus", em hebraico; ou seja, "ninguém" - símbolo, portanto, da humildade perante o Criador, tornado ainda mais miúdo pelo recurso ao diminutivo carinhoso que nomeia este personagem.

Miguelito, Miguelinho - ou, simplesmente, Miguilim, no sotaque interiorano brasileiro - torna-se alguém afetuosamente próximo de nós. A sabedoria de Tutaméia parece fazer eco à resposta da mãe à pergunta incômoda do Menino de "Campo geral": "- Mãe, mas por que é, então, para que é que acontece tudo? - Miguilim, me abraça, meu filhinho, que eu te tenho tanto amor." (ROSA, 1994: 541). É inegável o apreço de Rosa pelo olhar das crianças, voltado para os bichos e para a natureza, à maneira de Alberto Caeiro, que diz: "A Criança Eterna acompanha-me sempre/A direção do meu olhar éo seu dedo apontando./O meu ouvido atento alegremente a todos os sons/São as cócegas que ela me faz, brincando, nas orelhas". 
Há, no livro Ave, Palavra - reunião de anotações, poemas, diários e meditaçóes; publicado, postumamente, em 1970 -, em meio às descriçôes das inúmeras visitas que o autor fez aos grandes zoológicos e aquários do planeta, um curioso conto que menciona o circo, especificamente. Causa certa estranheza, pela temática absurda - ensaio insignificante do riso - que se distrai a descrever a vida dos insetos e suas peripécias sob uma verdadeira lente de aumento, arrancando do invisível e do imperceptível as aventuras e desventuras do mundo das criaturas mínimas: o "Circo do miudinho".

\section{O Circo do Miudinho, de Guimarães Rosa}

Sabe-se que os míopes têm essa inclinação para o detalhe, conseguindo enxergar melhor o que é menor e está mais perto, e tendo dificuldade para perceber as distâncias e a nitidez dos contornos. Miguilim é a história de uma criança que se descobre míope, uma criança que volta e meia reaparece, seja nas Primeiras estórias, como criança mesmo, seja noutra roupagem - a do representante simples do povo -, nas demais narrativas deste mineiro tão afeito à rude geografia do Brasil profundo. Através dos olhos de Miguilim, Guimarães Rosa transforma a sua severa miopia numa metáfora da nossa percepção, quando dependemos apenas do que os nossos olhos falhos podem captar, para traçar os nossos julgamentos neste mundo.

Besouro, louva-a-deus, grilo e cigarra: esta é a trupe de saltimbancos que se apresenta no picadeiro da estória, provavelmente inspirada no conto infantil Os músicos de Bremen, de autoria dos Irmãos Grimm. Na fábula original, destinada ao público infantil, quatro animais domésticos - um burro, um cáo, um gato e um galo -, já velhos e maltratados pelos patrōes, fogem de casa para formar um grupo musical e tentar a vida em liberdade, num lugar melhor.

A leitura adulta costuma aprofundar o sentido alegórico das fábulas, apontando suas implicaçóes satíricas e políticas. Um bom exemplo é a narrativa de George Orwell, $A$ revolução dos bichos, de 1945, que elabora uma dura crítica ao totalitarismo, dialogando com Os músicos de Bremen na sua contestaçáo do sistema feudal opressor. Em Bremen, os animais que representam as diferentes classes sociais submissas: o burro, os agricultores; o galo, os operários; o cão, os militares e o gato, os artistas, conseguem sucesso na sua empreitada. Orwell, contudo, vai além do desfecho simples da fábula, mostrando que a corrupção e a traição subsistem mesmo entre os rebeldes. Seu objetivo é denunciar a política stalinista que teria traído os princípios da Revolução Russa, em 1917.

A revolta dos animais da fazenda contra os humanos opressores é liderada por dois porcos. Os animais tentam criar uma sociedade utópica, porém 
Napoleão, seduzido pelo poder, afasta Bola-de-Neve e estabelece uma ditadura tão corrupta quanto o sistema anterior. Assim, Orwell mostra que o problema $\mathrm{da}$ injustiça social deve-se à natureza pecaminosa do próprio homem, capaz de corromper todos os ideais e converter todas as utopias numa mera "troca de cadeiras". A fábula é uma reflexão amarga contra o idealismo, e fala da desesperança do sonho de um mundo mais justo, onde todos tenham direitos e deveres iguais e trabalhem juntos para o bem comum. A música, que na história de Bremen tem um papel de hino, assume em Orwell os acordes da cançáo propagandística, perdendo sua alegria e a graça que infunde força e ânimo à luta dos oprimidos em busca da liberdade através da arte.

Ao contrário das fábulas usuais, Guimarães Rosa parece avesso ao uso da metáfora animal, consciente de que ela representa um aprisionamento dos bichos como homens. Sob este aspecto, sua fábula parece discrepante das demais, ao procurar ver o bicho como tal, e não como máscara humana. Distante do tema da luta de classes, ele parece mais interessado no desaparecimento planetário de outras espécies, esmagadas sob a égide ditatorial do humano na terra. Segundo John Berger, em "Por que olhar os animais?":

Os visitantes vêm ao zoológico para olhar os animais. Passam de jaula em jaula como visitantes de uma galeria de arte param na frente de um quadro, depois de outro e outro. ... Seja como for que se contemplem esses animais, mesmo se o animal se ergue contra as grades a menos de meio metro de nós, olhando para fora, para o público, estaremos olhando algo que se tornou absolutamente marginalizado, e toda a concentração que possamos exercer jamais será suficiente para torná-lo central. (BERGER, 1980: 28)

É conhecida a inclinação de Guimarães Rosa pela natureza, seja em sua ficção que elabora verdadeiros documentos da fauna e flora regionais, seja em suas pequenas e despretensiosas fábulas. Seu olhar é o do míope que, qual um cientista ao microscópio, precisa aproximar-se muito intimamente de seu objeto para poder percebê-lo, e no ato dessa aproximação acaba se despojando de preconceitos e molduras, descobrindo o imprevisível. Suas descriçôes das criaturas "miudinhas" - além do familiar diminutivo que revela a disposição afetiva de seu gesto, aproximando-as e acarinhando-as, divergindo, portanto, da frieza e da objetividade especulativas da observação científica - são poéticas como quem precisa sondar mistérios ainda destituídos de palavras. Às vezes, buscam onomatopeias, ritmos, compassos, sonoridades, como se a música conferisse maior propriedade à percepçấo do que as palavras, produzindo sobre estas um estranhamento e fundando uma nova língua.

Seu "circo" foge, portanto, à fórmula habitual do "Circo de cavalinhos", esquivando-se tanto do retrato dos grandes animais selvagens aprisionados e domados para o espetáculo, como do retrato dos animais domesticados para 
o uso consumista humano: de sua força, beleza, atributos físicos (pele, carne) ou psíquicos (companhia). Uma analogia possível seria com o "Circo de pulgas", excentricidade cuja existência é relatada desde o século XVI, e refere-se a uma exótica atraçáo, obra de relojoeiros, em que as pulgas aparecem ligadas a carrinhos em miniatura e outros itens, sendo postas a realizar performances dentro de uma pequena caixa.

Nada, porém, estaria tão distante do Circo do miudinho de Guimarães Rosa do que essas aberraçóes antropocêntricas, que apenas reproduzem, com os insetos, os procedimentos utilizados pelos adestradores dos bichos de maior porte, e que poderiam ser entendidos como pequenas legendas dos mecanismos de sujeição a que os homens, em geral, submetem os demais seres vivos que consideram "inferiores". Processos que não hesitam em aplicar aos seus semelhantes, quando lhes interessa diferenciar uma etnia, ou classe, ou gênero, como "menores". Por isso, John Berger (1980: 31) afirma que "todos os locais de marginalização forçada - guetos, favelas, prisões, hospícios, campos de concentração - têm algo em comum com zoológicos".

No Circo do miudinho não há exibiçôes, e o público humano, em geral, náo comparece, porque náo se interessa pelos eventos que se desenrolam diariamente ao seu redor. O seu picadeiro é o mundo ínfimo dos seres inatingíveis por um olhar afeito apenas às coisas "grandes". Adentramos neste circo pelo cotidiano relato de um observador que raramente interfere nas açóes desses seres, mas observa-as, buscando modos de capturá-las, nas palavras, sem violentar as suas breves existências.

Assim, no quarteto de Guimarães, cabe ao grilo o papel do cantor trovadoresco, ao lado da estridente cigarra. Acontece ao autor salvar uma cigarra cega-rega da morte, abocanhada pela gata Xizinha. Por uns instantes, segura-a na mão, observando sua semelhança com o besouro. "Feia, bela, horrenda": são adjetivos que buscam capturar a discrepância de seu corpo grosseiro dotado de asas impossíveis. "Era como as outras: a grossa cigarra de asas escritas, asas nervosas, as de cima mais compridas, manchas pretas nas costas, a cabeça larga, curta, vertical. Cigarra de ferro, renha cigarra. Trissilaba, frigideira, paroxistica". Nenhuma alusáo - como se esperaria depois da fantasia do grilo - à cigarra mambembe da conhecida fábula, sinônimo do artista irresponsável e da arte como excesso e desperdício, num conceito utilitário da vida onde a formiga é exaltada por seu caráter diligente e pragmático.

E então, o insight que atinge o observador imerso no sibilante ruído:

As cigarras se descascam, novinhas. E como que cantam, em hirta mentira, estridem. Longo tempo azucrinam, maquinazinhas; penteiam algo. Eu tinha de ouvi-las, no consciencio. Em crescendo. Em vários níveis. Tantos esses, no febril! Cada uma é um ponto de laminação carretel, vapor, fervor, orifício. 
Muitas se acertam, se acirram, insistidíssimas. Umas são mais secas. Calam-se a um tempo, repentinas. Cada uma despejou seu chio, parou, pôs-se a rolha. ... Quando ela pára, dói na gente. Vai-se até o coraçãozinho dela, dentro de um susto. (ROSA, 2001: 330)

A percepção afetiva que atinge o autor ao perceber o instante do silêncio da cigarra é capaz de conduzi-lo "até o coraçãozinho dela, dentro de um susto". Mas não é o silêncio que o surpreende no inseto que salva das garras da gata. A cigarra ameaçada de morte por uma inesperada tragédia parece experimentar o desespero de ver interrompida a sua metamorfose. Não ia "evoluir", ia morrer devorada:

E como ela guinchava, de horror, doida fortemente, estridulantérrima. Era um alarme terrível. Nenhum bicho se defende mais braviamente a brados, nem pede tão endiabrado socorro, quando nessas inóspitas e urgentes condiçóes. Vem de sua notória longevidade esse medo frenético de morrer? ... Nem me agradeceu. Perguntei, repreendendo-a: - Por que você grita tão exagerada? E: O senhor não acha que a vida mesma é que é um exagero? - foi sua terminante resposta. (ROSA, 2001: 330)

Há aqui, de fato, um esboço de releitura da conhecida fábula, ainda que por um viés impreciso. Neste caso, é o autor que ocupa o lugar do interlocutor da cigarra (a formiga?), embora não perceba o seu canto como "atividade artística” e, por isso, náo se sinta autorizado a bater-lhe a porta na cara quando ela lhe "pede ajuda no inverno". Apesar de rogar um "endiabrado socorro" nas "inóspitas e urgentes condições" em que se encontra, a cigarra real nada parece ter a agradecer ao seu benfeitor - atitude que ele registra com certo despeito, exigindo, inclusive, retratação. Como já fizera uma vez em sua bela releitura da fábula Chapeuzinho vermelho, intitulada Fita verde no cabelo, onde muda o tema do medo da iniciação sexual para o medo da morte (que se insinua na figura da avó da menina), aqui também o assunto é a passagem para um outro estágio do ser.

$\mathrm{O}$ artrópode, em seu processo de metamorfose, abandona o seu revestimento externo, duro e resistente demais para deixá-lo crescer. O "corpo" que fica para trás, ressequido e vazio, serve à perfeição para esta bem-humorada e "miudinha" meditação sobre a morte. A certa altura da vida, a cigarra secreta uma nova cutícula, e depois de romper o antigo invólucro através de uma fenda, consegue escapar. A nova "pele" da cigarra é mole e expansível, a "casca" que deixa para trás é apenas o esqueleto velho de uma fase mais jovem. As larvas de cigarra vivem no solo, e quando estão prontas para se tornar adultas, sobem pelos galhos e folhas, onde se prendem para passar pela muda, que é obrigatória ao seu crescimento. 
Assim, dialogando mais com as informaçōes científicas do que alegórico/ sociológicas sobre esse inseto, Guimarães Rosa elabora uma de suas microfábulas metafísicas, na qual reflete, com infinita graça - e desmanchando a moral da estória primeira -, que o dom artístico provavelmente náo é uma escolha, mas um fenômeno da natureza, talvez a manifestação de uma etapa evolutiva da espécie. Por isso, o "canto" que distrai o artista da realidade empírica não é recusa arrogante ou leviana das obrigaçóes mesquinhas que sujeitam os outros, mas o mero e inevitável cumprimento de uma destinaçáo que lhe foi designada. Por isso, ao "cantar" não se deve associar apenas a manifestação de uma alegria irresponsável, há também dor e desarrazoado medo um medo "estridulantérrimo" - preso no âmago do "coraçãozinho" daquele que não pode senão cantar.

A "caridade" que se deve a um saltimbanco poeta, em resposta ao anúncio de um novo tempo que ele prega para nós, com as cores e os acordes de sua sensibilidade, é táo somente a nossa obrigação. Porque não é o artista o responsável pela missão que professa, mas a própria vida que o aprisiona nessa cutícula. Dessa forma, o interlocutor obtém a única resposta que podia à sua inclemente indagação: não é a cigarra que é exagerada e excessiva, é a existência que é uma arte implacável, absurda e rebuscada. Exigente - em seu anseio de eternidade - como quem se debate na boca de um gato... ou de um cáo.

\section{O Circo da Pandorga, de Osman Lins}

Tanto faz ser saltimbanco como assaltar bancos, tanto um frade calçado como um fracassado. Lê-ô-lá! É noite e é dia, é aqui e é lá, sou e não sou eu, a mutação, a passagem, o trans,

vou indo e já cheguei. ...Lê-ô-lá, ela me dá o braço, somos uma vez, entramos por uma perna de pinto, saímos por uma perna de pato, vamos por aí, ela e eu, em direção aos impossíveis limitíferos, ao erumavezífero, ao Recífero, às portas abertíferas, ao bacorífero, ao eixo universífero, ao ir sem regressífero, ao amplífero, ao putaqueparífero, ao imensífero, ao ífero, ao Baçirabacífero.

Osman Lins, A rainha dos cárceres da Grécia

Como todo menino de interior, Osman Lins - natural da cidade de Vitória de Santo Antão, na zona da mata pernambucana, onde as distraçôes eram poucas e a vida monótona - tinha grande fascínio pelo circo. Entretanto, percebe-se algo de melancólico na forma como este espaço de alegria e descontração é adaptado no cenário de suas narrativas. "Pentágono de Hahn", da coletânea Nove, novena (1966), é um texto explicitamente dedicado ao tema, abrangendo, inclusive, uma estória anterior, publicada no livro Os ges- 
tos (1957), cujo título é exatamente este: "Conto de circo". O que sobressai na obra é justamente a sofisticaçâo de sua estrutura, que traduz as elaboradas preocupaçóes estéticas osmanianas dessta fase, voltadas para o experimentalismo narrativo e para as inovaçóes composicionais.

Chama a atenção a transposição das formas do picadeiro, que do usual círculo - generosa e francamente acessível à visibilidade do público distribuído nas arquibancadas em volta - passa a ser um "pentágono": polígono anguloso, com cinco lados que escondem cinco estórias diferentes e intercaladas, cuja visibilidade é dificultada ao leitor pela fragmentação e superposição dos enredos, introduzidos por símbolos que identificam as falas de diferentes "mestres de cerimônias", ou narradores. E o título do conto, estrangeiro: $H a h n$ - que em alemão significa "galo" - é tão mais enigmático quanto menos se refere à personagem que traz esse nome: uma imensa e absurda elefanta, ponto central do pentágono que deveria ser círculo, para onde convergem todas as linhas narrativas.

Embora Osman Lins não tenha escrito para crianças, há duas estórias que compôs com a intenção de distrair essa faixa etária: a peça $O$ diabo na noite de Natal, escrita a pedido de uma filha, e uma estorinha intitulada Exercício de imaginação, escrita a pedido da filha de um amigo, publicada na coletânea Liçôes de casa, organizada por Julieta de Godoy Ladeira. Foram as únicas concebidas intencionalmente pensando nos jovens, e são as criaçôes osmanianas mais engraçadas - ao lado da comédia mambembe Lisbela e o prisioneiro (1962), que tanto sucesso alcançou nas telas do cinema e da televisão nos anos 1990 .

Ambientada no espaço rural, a peça ridiculariza a fanfarronice do nordestino nas figuras antológicas do assassino profissional Frederico Evandro e de Leléu, o artista de circo mulherengo, sem prejuízo da sinceridade sobre a história de amor que é narrada. Com a peça, Osman Lins já apontava, nesse início de carreira, para o caminho da leveza e do humor que talvez viesse a recuperar numa fase tardia da sua produção. Essa tendência se anunciou com a irreverente Maria de França, de seu último romance publicado, A rainha dos cárceres da Grécia (1976), que ao lado de um espantalho - o Báçira -, ataca desvairadamente, com ímpetos quixotescos, a crítica literária de seu tempo. E ameaçou vir à tona em toda a sua pujança com o desancado e desbocado José Apolinário, figura de seu romance inacabado, A cabeça levada em triunfo, no qual se anunciava uma possível e definitiva virada em sua poética.

Jamais saberemos, contudo, o que viria a fazer Osman Lins se não tivesse abandonado tão cedo o picadeiro deste mundo. O que podemos constatar é que, até a sua morte, tais composiçôes ainda não haviam aberto plenamente uma vereda de alívio no íntimo do escritor, ainda conduzido pelo implacável 
dedo em riste de um Menino triste e magoado, que se sentia sozinho e responsável pela morte de sua jovem mãe: "O traço fundamental da minha vida é que, dezesseis dias depois que nasci, perdi minha mãe. Fui criado pela minha avó, por outros parentes... Minha mãe não deixou fotografias, de modo que eu fiquei com essa espécie de claro atrás de mim. Isso configura a minha vida como escritor, pois parece que o trabalho do escritor, metaforicamente, seria construir com a imaginação um rosto que não existe".

É esse o Menino que ele conserva na alma, concentrado a brincar gravemente com Deus as cinco pedrinhas no degrau da porta de casa, ao anoitecer: "como se cada pedra fosse todo um universo/e fosse por isso um grande perigo para ele/deixá-la cair no chão”. Faltava-lhe, ainda, liberar a Criança Nova de que fala Alberto Caeiro, aquela que, dando uma máo ao poeta e outra a tudo que existe, conduz a tríade pelo caminho que houver: "saltando e cantando e rindo/e gozando o segredo comum/que é o de saber por toda a parte/que não há mistério no mundo/e que tudo vale a pena”.

Das narrativas do livro Nove, novena, cinco trabalham a imagem da criança, ou do adolescente na passagem para a vida adulta: "O pássaro transparente", "Pentágono de Hahn", "Retábulo de santa Joana Carolina", "Conto barroco ou unidade tripartita" e "Perdidos e achados". Em todas elas, encontram-se pinceladas autobiográficas e fragmentadas daquele Menino, esboçado com inteireza em Ascânio, personagem de seu primeiro romance de sucesso, O fiel e a pedra (1961). Essas pinceladas se insinuam com grande frequência em sua obra, assinalando a continuidade do mote da criança órfă ou da criança morta a conduzir o fio de suas estórias.

Em apresentação ao livro O fiel e a pedra, Massaud Moisés faz uma observação interessante sobre a literatura osmaniana: a de que ela padece de "falta de humor". Ressalta ele a presença de uma "mundividência orientada pelo signo da comoção e por uma gravidade lírica, compassiva e despida de humor: a seriedade com que encarava a vida e a literatura, entrelaçadas e confundidas, e que obrigava o escritor a repudiar, desde o começo, o sorriso ou o ato inconsequente." (MOISÉS, 1979: 13).

Pentágono de Hahn, portanto, nem de longe se aparenta ao ignóbil cirquinho de interior, lindamente encenado no despretensioso enredo de Lisbela eo prisioneiro, com seus palhaços, mágicos, equilibristas e malabaristas da vida, cumprindo seus papeis com muita graça e levando diversão e encantamento à plateia. Nem ao circo infantil da fábula natalina que articula vários gêneros, desde os clássicos europeus para crianças até os desenhos animados americanos e filmes do palhaço Carlitos, passando pelas lendas regionais do Negrinho do Pastoreio e do Amarelinho, e de folguedos populares como o Pastoril, todos reunidos no emblemático picadeiro do Sítio do Picapau Amarelo do brasi- 
leiro Lobato, o pai da literatura infantil nacional, para narrar a empedernida luta do menino Jesus, vulgo Pequeno Príncipe, e seus companheiros e companheiras contra o "Capeta", "o cão do segundo livro". Tampouco ao diálogo dos dois adoráveis e absurdos bichos, construídos num exercício escolar "de imaginação", que vão ganhando vida na página a partir da decomposição e recomposição das palavras de seus nomes, como se surgissem diretamente da brincadeira carroliana de um Menino redator/redentor, na sua cartilha de primeiras letras:

$\mathrm{O}$ pássaro, a menina, a bola e o gato. $\mathrm{O}$ gato, a bola, a menina e o pássaro. $\mathrm{O}$ pássaro a bola o gato a menina. A menila o pasto a bona e o gásaro. A Pastomenila e o Bonagásaro. Encontraram-se um dia, numa encruzilhada, a Pastomenila e o Bonagásaro. (...)

- E amanhã, às 10 horas, no máximo, chegam as aves.

- O Pavão também?

- Não.

O Bonagásaro mastigou a palavra "náo", engoliu-a e começou a saltar extremamente irritado. "Por que o Paváo náo vem? Por que não vem o Pavão? $\mathrm{O}$ Pavão náo vem por quê?" Seu bico vermelho parecia uma espada, enquanto ele explorava as possibilidades sintáticas da frase. Quando silenciou, disse a Pastomenila:

- O Pavão chega hoje com os leóes.

O Bonagásaro bradou: - Por quê? Quem deu ordem?

A Pastomenila começou a girar, tilintando a cristalina dentadura. Abriu de súbito as asas de palheta e enlaçou chorando o Bonagásaro, que ficou menor. (...) Regiraram os dois, ouviu-se em meio àquele torvelinho, com um rumor de taça quebrada contra as pedras, a palavra ARPRIMEVA! Cessado o vento, eram outra vez, na página, o gato, a menina, a bola e o pássaro. Não havia sinal de Pastomenila nem de Bonagásaro. Cerrei os dentes e ergui a cabeça, à espera do Pavão, com sua imponente guarda de leóes. (LINS apud LADEIRA, 1979)

Não. As histórias circenses de Osman Lins não detêm esse ar leve e numinoso; são antes evocaçóes sombrias e desamparadas, nas quais chora a sombra do menino órfẫo e do menino morto, que não se perdoou e, por isso, ainda não consegue perdoar. Semelhante ao "Pavão, com sua imponente guarda de leóes”, esse implacável Menino traduz uma ideia de peso, qual a elefanta escanchada na praça central da estória, que nenhuma leveza ou alegria é capaz de infundir às criaturas à sua volta. Todas convergem para ela com seus dramas e suas dores pessoais, sérias, sóbrias e excessivamente cônscias da monumentalidade de suas próprias tragédias.

Assim, acabam conduzindo mal os seus destinos: Helônia, a sonhadora virgem de 70 anos, ao perder seu último pretendente, comete o suicídio por enforcamento; a moça mal amada que habita um corpo considerado feio ou desarmônico colhe migalhas de afeto, seduzindo um pré-adolescente; o irmão 
do meio de Oséas e Armando, celibatário, busca inutilmente o amor entre aquelas que o vendem por dinheiro; o rapaz desiludido com o casamento e com a mulher "que deixou de amar" revisita melancolicamente um passado que não pode reviver, junto a uma avó a quem esquece a maior parte do tempo. Dentre tantas criaturas mesquinhas e desagradáveis, comentarei brevemente a estória do "menino das pandorgas", que me parece o mais simpático.

Um tanto deslocado entre os demais moradores da horrível cidade a qual nem um circo consegue alegrar, essa criança divide-se entre a aspiração nascente do amor - topos geral do conto - e o sonho de ascender, escapar, talvez, no voo do pentágono de papel do brinquedo adorado (forma convencional da pipa), da torpe e doentia realidade em que se descobre existindo (e que, diga-se de passagem, apenas reproduz um modo cansado de olhar para o circo do mundo, o mesmo circo no qual os saltimbancos se divertem por opção, quase como uma afronta à vida madrasta...).

O conto gira em torno das mirabolantes peripécias narrativas convocadas por Osman Lins para disfarçar o significado da descoberta do desejo, que no menino é despertado por Adélia, a vizinha mais velha e casada. "Pandorgas" que sobem para o céu, como "índios vermelhos", manipuladas pelo garoto; abraços que são dados em troncos nodosos, onde se arrastam lagartas de fogo que queimam o rosto, que depois será beijado pela amada; aguaceiros que tombam do céu para molhar as vestes do casal, colando-se aos seus corpos e revelando suas formas íntimas... por aí seguem os jogos malabares do autor para falar de sexo, em lances que, de tão explícitos e descabidos - talvez inadvertidamente, e enfatizados pelo contraponto com a compungida seriedade geral da narrativa -, conseguem ser realmente engraçados.

O que estabelece um diferencial nesta estória, em relação às demais, é a quase inconfessável irreverência da criança, a sua independência mesmo em face aos revezes da vida - quando rasgam seu brinquedo e perseguem-na, apedrejando-a -, e mesmo quando se percebe ainda distante da realização das alegrias que intui, não sem malícia, existir na vida sexual dos adultos (pois Adélia não o leva a sério, tratando-o como a criança que é). Há, no menino, uma insubordinação latente que se verifica nos demais ensaios de liberdade e leveza aos quais se atreveu Osman Lins; e que falam, por exemplo, de seu apreço pelo aspecto mambembe da vida, apesar de seus esforços para revestir os seus textos de um rígido escafandro intelectual.

Transcrevo um belo trecho da narrativa em que o entusiasmo pela festa pastoril supera a triste exibição da elefanta importada: indicativo deste comichão interno em busca do Menino feliz que não raro acometia o autor e que, decerto, teria vindo à tona, confortavelmente, numa poética da maturidade 
que ele não pôde viver. Livre de obrigações e penitências, vale pela promessa explícita de uma grande e terapêutica alegria, que nos contagia a todos:

Dentre os papagaios que, nos ares infestados de varíola, planam serenos, surgiu a Novidade, o Acontecimento. Um pastoril famoso divide com Hahn as atençōes das pessoas. Num estrado alto, de madeira, as pastoras cantam, fortemente pintadas... A orquestra: um pífano, um banjo e um triângulo). Ora o empresário, nos dias em que as dançarinas-cantoras se apresentam, descobriu este modo festivo de anunciar ao povo o espetáculo: às quatro e meia, solta um papagaio azul, rubro e laranja, por ele construido e que não imita os outros, nenhum outro. É enorme, régio, rosnador, em mais de um plano, cheio de festóes, parecido com um peixe, um gavião, um guarda-chuva, um porta-bibelôs, uma girândola. Encanta-me. Decidi fazer um papagaio assim, formas novas, diferente dos outros e ainda mais alegre. Vou fazế-lo. (LINS, 1999: 42, grifos nossos)

Tal veemência parece corroborar o desejo por uma narrativa capaz de se dissolver no riso que salva, no circo do miudinho, no terreiro de Lisbela. Uma narrativa capaz de gracejar do Prisioneiro ao vê-lo atacar, com suas razóes de inseto, a enormidade da Lei, a implacabilidade da Sentença. O Processo nos ensina a rir de estilos, gêneros e movimentos literários, quando, mesmo pequenos, só têm um sonho: "preencher uma função maior da linguagem, fazer ofertas de serviço enquanto língua de Estado". Como diz Deleuze e Guattari a respeito de Kafka, "é preciso cultivar o sonho contrário: saber criar um devir menor":

A literatura é mais assunto do povo do que da história literária. ... A questão individual, ampliada ao microscópio, torna-se muito mais necessária, indispensável, porque uma outra história se agita no seu interior. ... Estar-se na sua própria língua como um estrangeiro. Ainda que única, uma língua é sempre uma caldeirada, uma mistura esquizofrênica, um traje de Arlequim através do qual se exercem funçôes de linguagem muito diferentes e centros de poder distintos, ventilando o que pode ser e não ser dito. ... Só o menor é que é grande e revolucionário. (DELEUZE, 2003)

Para Bakhtin, o carnaval, que tem íntimas relaçóes com o circo, não é só uma prática social específica, mas também uma reserva geral e ininterrupta de formas populares e rituais festivos, que promove a aproximação dos contrários - as mésalliances do sagrado e do profano, do alto e do baixo, da ordem e do caos. Ao longo da história, o riso foi perdendo seu elo essencial e renovador numa concepção demasiado severa do mundo, reduzindo-se ao domínio do particular e do típico:

Ao contrário da festa oficial, o carnaval era o triunfo de uma espécie de liberação temporária da verdade dominante e do regime vigente, de aboliçâao provisória de todas as relaçôes hierárquicas, privilégios, regras e tabus. Era a autêntica festa do tempo, a do futuro, das alternâncias e renovaçôes. Opunha-se a toda 
perpetuação, a todo aperfeiçoamento e regulamentação, apontava para um futuro ainda incompleto". (BAKHTIN, 1987: 9)

Por isso, é preciso que autores como Guimarães Rosa e Osman Lins surjam de tempos em tempos com suas propostas carnavalizadoras, trazendo para a cena, novamente, a explosão de alteridade que faz renascer a graça das cinzas. $\mathrm{O}$ espetáculo mambembe do circo derruba as barreiras hierárquicas, sociais, ideológicas, de idade e de sexo, numa grande celebração da vida, cujo propósito é promover a reaproximação dos seres, a alegria das trocas, evocando as origens e a infância. Como diz Alberto Caeiro, que os poetas nos socorram e a vida nos ensine o aprendizado do Menino, para que a alegria náo nos abandone jamais:

Quando eu morrer, filhinho,

Seja eu a criança, o mais pequeno,

Pega-me tu ao colo

E leva-me para dentro da tua casa.

Despe o meu ser cansado e humano

E deita-me na tua cama.

E conta-me histórias, caso eu acorde,

Para eu tornar a adormecer.

E dá-me sonhos teus para eu brincar

Até que nasça qualquer dia

Que tu sabes qual é. (PESSOA, 2005: 210)

\section{Referências}

BAKHTIN, Mikhail. A cultura popular na Idade Média e no Renascimento: o contexto de François Rabelais. São Paulo: Hucitec, 1987.

BERGER, John. Sobre o olhar. Barcelona: Gustavo Gili, 1980.

CAEIRO, Alberto. "O guardador de rebanhos". In: PESSOA, Fernando. Obra poética. Rio de Janeiro: Nova Aguilar, 2005.

CURI, Simone. Ensaio insignificante do riso. In: DUARTE, Lélia Parreira (Org.). Veredas de Rosa II. Belo Horizonte: PUC-MG, 2003.

DELEUZE, Gilles; GUATTARI, Félix. Kafka: por uma literatura menor. Lisboa: Assírio e Alvim, 2003.

FERREIRA, Ermelinda. Decapitados: homem e estilo no romance inacabado de Osman Lins. In: FERREIRA, Ermelinda (Org.). Vitral ao sol: ensaios sobre a obra de Osman Lins. Recife: Edufpe, 2004.

GRIMM, Wilhelm. Os músicos de Bremen. São Paulo: Ática, 2012.

LADEIRA, Julieta de Godoy (Org.). Liçôes de casa - exercícios de imaginação. São Paulo: Livraria Cultura Editora,1979.

LINS, Osman. Os gestos. São Paulo: Melhoramentos, 1975. 
. Nove, novena. Narrativas. São Paulo: Companhia das Letras, 1999.

- A rainha dos cárceres da Grécia. São Paulo: Melhoramentos, 1976.

. Avalovara. Rio de Janeiro: Guanabara, 1986.

. Lisbela e o prisioneiro. São Paulo: Planeta, 2003.

LISBOA, Adriana. O circo do miudinho: Guimarães Rosa e a poética do pequeño. In: DUARTE, Lélia Parreira (Org.). Veredas de Rosa II. Belo Horizonte: PUC-MG, 2003.

ORWELL, George. A revolução dos bichos. São Paulo: Companhia das Letras, 2007.

RAMOS, Jacqueline. Risada e meia. Comicidade em Tutaméia. São Paulo: Annablume, 2009.

ROSA, João Guimarães. Tutaméia. Terceiras estórias. Rio de Janeiro: José Olympio, 1967.

. Ave, palavra. Rio de Janeiro: Nova Fronteira, 2001.

. Manuelzão e Miguilim. (Corpo de Baile). Rio de Janeiro: Nova Fronteira, 2001. . Primeiras estórias. Rio de Janeiro: José Olympio, 1981.

. Grande sertão: veredas. Rio de Janeiro: Nova Fronteira, 1986.

Ermelinda Maria Araújo Ferreira é formada em Medicina e Letras, doutora em Letras pela PUC-Rio, com pós-doutorado na Universidade Nova de Lisboa. É professora do programa de pós-graduação em Letras da Universidade Federal de Pernambuco (UFPE), colaboradora do Instituto de Estudos Modernistas e Pessoanos da Universidade Nova de Lisboa (IEMO) e do programa de pós-graduação em Literatura e Interculturalidade da UEPB. Coordena o Núcleo de Estudos em Literatura e Intersemiose (NELI/CNPQ - http://www.neliufpe.com.br), onde é editora da Intersemiose - Revista Digital. Publicaçóes recentes: FERREIRA, Ermelinda (Org.). Literatura e medicina (Recife: Edufpe, 2012); FERREIRA, Ermelinda (Org.); Corporalidades e afetos (Recife: NELI/CNPq, 2014). E-mail: ermelindaferreir@uol. com.br. 